\title{
Internalizing the Local Wisdom Value of Nyadran Tradition to Students through Audio Visual Media
}

\author{
Yuliningsih $^{1}$, Kundharu Saddhono ${ }^{2}$, Budhi Setiawan ${ }^{3}$ \\ \{yuliningsih360@gmail.com ${ }^{1}$, Kundharu.uns@gmail.com ${ }^{2}$, buset.74@gmail.com ${ }^{3}$ \} \\ ${ }^{1,2,3}$ Universitas Sebelas Maret Surakarta, Indonesia
}

\begin{abstract}
The flow of globalization is running so fast in various fields, one of which is in the field of education. To overcome the negative impact of globalization in the field of education there is a need to internalize the value of local wisdom to students through the Nyadran tradition of audio-based learning media. This study used descriptive qualitative method. The purpose of this study is to shape the character of students through the value of local wisdom in the Nyadran tradition with video-based. Data was obtained through observation and in-depth interviews with indigenous stakeholders, teachers, and students. Data analysis techniques use interactive chain analysis with the steps of data collection, data reduction, data presentation, and conclusion drawing. Based on conclusions, the results of this study indicate the existence of communicative, caring, peaceful, tolerant, religious and sharing character values that are developed from the local wisdom values of the audiovisual based of Nyadran tradition. Nyadran material using audio visual technology makes learning interesting and educates students' character in getting used to thinking and acting according to cultural values.
\end{abstract}

Keywords: local wisdom value, Nyadran tradition, audio visual media

\section{INTRODUCTION}

The degradation of moral and character values in students is one of the things that becomes a concern in the world of education. One way to overcome moral and character degradation is to instill character values through local traditions. One tradition that has the value of local wisdom is the nyadran tradition. The nyadran tradition is ancestral heritage that developed in the Indonesia Central Javanese community, this tradition is a symbol of the relationship with the ancestors, fellow humans, and the almighty one. Nyadran is held once a year in the dry season and at the same time as a people's party after harvest. In the beginning nyadran was carried out by Javanese society as an expression of worship of ancestral spirits and after the presence of Walisongo in Java, the ritual was transformed into the value of local wisdom of Islamic culture [1]. The cultural values are taken from the purpose of nyadran which is a form of expressing gratitude to the Lord for the abudance of fortune. 
Local wisdom in the nyadran tradition can be a means of identifying thought patterns that lead to a view of life [2]. The nyadran tradition has the meaning and value of local wisdom as the formation of children's character that can be taught early. To achieve educational goals, collaboration between learning practices and student needs is needed, thus preparing students for the 21 st century which demand high skills and social interaction [3]. The education world must be able to keep abreast of developments and advancements in the days based on information and communication technologies (ICT). The teaching material for the nyadran tradition will be more concrete and easy to understand if the material is presented and delivered by the teacher through audio visual. This is to facilitate students in implementing local wisdom values in everyday life [4].

Through education, the spirit of nationalism can be inserted and instill into the character of students by integrating the values of local wisdom in teaching [5]. As a result, respect and love for their culture grew. In the process of integrating the value of local wisdom in the realm of education, a teacher must adapt the material to the level of students' growth. Local wisdom valuebased learning educates students to always be close and able to overcome real problems in everyday life. In addition, students' cultural insights will become global and local knowledge as a provision for students to form personalities. Students will feel happy with high-level teaching and learning from local learning units then entered into ASEAN which is designed in the form of more interesting learning activities [6]. The value of local wisdom can reflect the value of Javanese way of thinking that can be seen and imitated in the context of spiritual meaning, imagination, sensitivity, creativity, values of manners, and harmony [7].

The integration of character education based on local culture is very important to be applied in schools [8]. The values of morality that are believed to be true by the public should be implemented in learning that follows the flow of globalization [9]. Today, as globalization is marked by the advancement of the world of information and technology, it provides many changes and pressures in all fields. If this is not accompanied by the sensitivity of the community to maintain identity with various cultural values it will have a negative impact on students. Culture and tradition must be preserved by the younger generation because in culture they have local wisdom values that can control bad deeds [10]. In culture there are many noble values and cultural norms that govern the lives of the people and are used as a life view or philosophy of human life [11]. The development of technology directly and indirectly will be a factor in the crisis of moral values and character in students. Therefore, it is necessary to internalize the value of local wisdom in the nyadran tradition to students through audio-visual media. The nyadran tradition is local Javanese inheritance which has character values, making it suitable to be included in the curriculum and taught to students.

\section{RESEARCH METHODS}

This research is descriptive qualitative with the main focus of describing and explaining the value of local wisdom in the nyadran tradition as an alternative audio-based teaching material for the formation of students' character. Culture-based descriptive qualitative method is a descriptive method and logical definition method that links values in culture with real life [12]. The source of qualitative data is the audio visual based of nyadran tradition ceremony. The techniques of collecting data are through observation and in-depth interviews with traditional stakeholders, 
elementary school teachers, and elementary school students. In collecting data, the selection of informants must be adjusted to the research objectives [13]. To guarantee the validity of the data needed in this study, the data validity test was carried out using data triangulation. Data triangulation is used to check the validity of data by utilizing other things [14]. The data analysis technique uses interactive chain analysis with the steps of data collection, data reduction, data presentation, and conclusion drawing.

\section{RESULT AND DISCUSSION}

\subsection{Local Values of Nyadran Tradition Based on Audio Visual}

Education does not only provide knowledge, values and skills, but education also has a function to help students develop all their potential, skills and personal characteristics in a better direction, both for themselves and their environment [15]. To develop the personality and character of students there is a need for teaching material that has local wisdom values. Teaching materials of the nyadran tradition can be taught to students through audio-visual learning media in the form of videos. Video learning media is a combination of conventional learning methods with ICT-based audio visual. Through video-based learning, students can make observations, explore, and even communicate what is in the procession of the nyadran tradition. Therefore, audio-visualbased learning media are able to support and simplify students' learning processes in accepting the delivery of nyadran tradition material as the formation of student character. The use of strategies and learning media aims to increase knowledge and understanding [16]. Thus, the use of media and learning strategies need to be developed by the teacher. Audio visual media is an important component to overcome all barriers to learning communication outside the classroom [17]. Media is one of the learning aids, facilities / places of learning, and as a learning resource for students to improve competence and attitude. Character building is an important part of the world of education today. Law of the Republic of Indonesia No. 20 of 2003 [18] concerning the national education system states that the goal of national education is to develop capabilities and establish a dignified national character and civilization in order to educate the life of the nation. To realize these goals, character education should be given to children as early as possible. If early on children are introduced to traditions that contain moral education and character, then later if they become adults, they will have good character [19]. One way to shape children's character is by introducing traditions in which there is a value of local wisdom. The nyadran procession that has noble values as character building can be seen in the description table below.

Table 1. description of the results of the nyadran tradition procession

\begin{tabular}{ll}
\hline Nyadran Procession & Local Wisdom Value \\
\hline The formation of the nyadran committee & Deliberation \\
Clean tombs and punden & Mutual cooperation, care for the environment \\
Cook food and offerings & Communicate \\
Bancakan & Peaceful love, religious \\
Andhum sodaqohan & Mutual haring \\
Nyadran on Punden Mbah Gedhong & Harmony, religious \\
Punggahan & Generous, religious \\
\hline
\end{tabular}


From the value of local wisdom contained in the nyadran ceremony procession can shape the character and personality of students. The characters that can be formed through the nyadran tradition include religious, tolerance, communicative, love of peace, and caring for the environment.

\subsection{Value of Local Wisdom of the Nyadran Tradition as Formation of Students' Character}

Tradition has the value of mutual cooperation, unity and integrity, deliberation, social control, and local wisdom. Moral values that can be taken from the implementation of nyadran are vertical moral values and horizontal moral values. Vertical moral value means a relationship that must be nurtured spiritually and harmoniously between humans and God through the nyadran ceremony as a form of expressing gratitude for the blessing of abundant fortune. Meanwhile, moral values horizontally explain the positive relationship between humans and humans, humans and animals, and the natural environment. Thus, a natural balance is created. From the nyadran tradition, it can be concluded that humans in their daily lives must always be responsible managers, meaning that they can treat animals and the natural environment in a balanced manner, not to do damage, so as to avoid disaster. The local wisdom values of the nyadran tradition in detail can be described as follows:

\subsubsection{Value of deliberation}

As shown before the ceremony of the nyadran tradition, there was a large meeting to form the Nyadran committee. This deliberation is usually referred to as citizen discussion. This can form a communicative character in students.

\subsubsection{Value of mutual cooperation and environmental care}

The value of mutual cooperation and environmental care is realized by all residents while cleaning up the tomb and cleaning the village environment together. This can form the character of environmental care in students.

\subsubsection{Communicative values}

Communicative behavior is shown by women when cooking food and preparing offerings that will be used in the nyadran ceremony. With pleasure they asked each other if there were still deficiencies in preparing food and offerings. Without communicative behavior between the women, there will be a miss communication in preparation for the nyadran ceremony. In addition, communicative behavior is also shown during the nyadran procession, which when heading to the graves, all residents walks and are not permitted to carry a vehicle. This is to make all citizens can greet each other, so that the relationship is maintained. From these behaviors, it can form communicative characters in students that can be manifested in daily behavior, both within the school and society.

\subsubsection{Value of harmony}

The value of harmony is manifested by the community which creates peace and tranquility before the nyadran lasts until nyadran is finished. Thus, the nyadran tradition can be developed into culture and tradition in the community. It can shape the character love of peace in students. The character of love of peace can be applied to students of different faiths, races, and tribes by maintaining mutual harmony.

\subsubsection{Value of sharing, tolerance and a sense of unity}

The nyadran traditional ceremony was carried out by residents who adhered to Muslim beliefs, but it is undeniable that there were some non-Muslim citizens who also helped contribute their 
labor such as taking part in carrying out community service and cleaning the tomb. At the end of the nyadran tradition ceremony, participants set aside some food to be distributed to residents who were non-Muslim. Although there is a different belief, tolerance among citizens is very strong, which makes people live in harmony side by side and do not interfere with each other. We can see how the feeling of sharing, tolerance between fellow humans by realizing a sense of unity and integrity. This behavior can be applied to students to develop the character of inter-religious tolerance with mutual respect.

\subsubsection{Religious values}

The religious values contained in the nyadran tradition cannot be separated from the values of Javanese culture. In the Javanese context, the religious value of the nyadran tradition is associated with efforts to maintain memories so as not to forget their origins [20]. The Javanese ancestors had a wise will: manungsa aja lali wetone. Mula elinga marang wong-wong tuwa senajan wis padha swarga which means that humans do not forget the day of birth, then remember the old people even though they are in heaven. This can form a religious character in students by praying for deceased ancestors.

The value of the nyadran tradition has outlined the values of the principles of local traditions and religious teachings [21]. The values of the principle include the feeling of $u k h u w a h$, love, help each other, amar ma'ruf nahi munkar, and the similarity that every human being will surely return to the Khaliq. The tradition of nyadran has become a religious teaching in which it has the activities of prayer for safety, recitation of the prayer of the Prophet, and tahlilan grave pilgrimage as well as expressing gratitude to the creator of nature for the blessing of abundant fortune.

\subsubsection{Generous value}

As shown by residents who exchange food and produce on the morning after the nyadran ceremony, the tradition of content is called punggahan. The activity is a form of character education to share with others.

\subsection{Relevance of Nyadran as an Alternative Learning Material}

Noting aspects of technological and information development, the nyadran tradition material is designed in audio visual in the form of video. Video is a learning medium in which children can see and listen to themselves what they are learning. The video teaching media of nyadran tradition has advantages: (1) it can improve the competence of students in the local culture of Javanese society which has begun to be eroded by modernity. Students get in-depth reflection about the heritage of their ancestors; (2) can be an alternative learning resource to synchronize the theories obtained from classroom learning with local cultural conditions that live around students; (3) the material is designed according to the character of students and the character of the environment of the Javanese culture that can help students improve cognitive, affective, and psychomotor competencies; (4) can be arranged systematically and can help educators and students achieve the expected learning goals, and (5) can develop students' character in accordance with their environment, and increase awareness and pride in their own culture. Students are not only able to know the culture of nyadran, but more deeply students are able to understand the values of local wisdom in the tradition of nyadran to then be applied in daily life as a form of character formation of students [22]. 


\section{CONCLUSION}

Nyadran has the value of local wisdom that can be used as a capital for the formation of communicative, caring, peaceful, tolerant, religious, and sharing characters on students that are developed from audio-visual materials. Wisdom values in the nyadran tradition include (1) deliberation which is shown in a meeting to form a committee of nyadran; (2) the value of mutual cooperation and environmental care is realized by the activity of cleaning the tomb and cleaning the village environment together; (3) creative and communicative values are shown during the process of cooking offerings; (4) the value of harmony, manifested by peace and quiet during the nyadran procession; (5) the value of sharing, tolerance, and a sense of unity shown by the attitude of mutual assistance between religious people during the nyadran procession; (6) religious values are shown by the expression of gratitude to the Lord by praying and reading short letters; and (7) generous value, indicated by residents who exchange food after the nyadran ceremony. Students are not only able to know the culture of nyadran, but more deeply students are able to understand the values of local wisdom in the tradition of nyadran to then apply it in daily life as a form of character formation of students. Thus the video of the nyadran tradition can be a medium to educate students' character in getting used to acting and thinking according to values.

\section{REFERENCES}

[1] Hasanah \& Hasyim. "Implikasi Psiko-Sosio-Religius Tradisi Nyadran Warga Kedung Ombo Zaman Orde Baru (Tinjauan Filsafat Sejarah Pragmatis)". Wahana Akademika, Vol. 3, No. 2, pp. 18-34, 2016.

[2] K. Saddhono, F. N. Fatimah, and E. T. Sulistyo. "Membangun Kearifan Lokal Melalui Karya Sastra Dan Budaya Daerah (Jawa)". Prosiding Seminar Nasional Bahasa dan Budaya, pp. 8$17,2017$.

[3] T. Sugita. "Current Trends in Psychological and Educational Approaches for Training and Teaching Students with Autism in California". International Electronic Journal of Elementary Education. Vol. 9, No. 2, pp. 307-316, 2016.

[4] S. Kima and K. Lee. "Development and Validation of Self-directed Learning Ability Test (SDLAT) for Elementary School Students. International Electronic Journal of Elementary Education. Vol. 10, No. 5, pp. 551-557, 2018 . DOI: 10.26822/iejee.2018541304

[5] A. M. Albantani and A. Madkur. "Think Globally, Act Locally: The Strategy of Incorporating Local Wisdom in Foreign Language Teaching in Indonesia international Journal of Applied Linguistics \& English Literature”. IJALEL. Vol. 7, No. 2, pp.1-8, 2017.

[6] T. Wangkaewhiran. "Development of Local Wisdom Learning Management Model of ASEAN Focus School: A Case Study in Thailand". A paper presented in The Asian Conference on Education, 2012.

[7] S. Subiyantoro. "Rumah Tradisional Joglo Dalam Estetika Tradisi Jawa”. Bahasa Dan Seni. Vol. 1, pp. 68-78, 2011.

[8] T. La, L. O. A. Basri, L. O. Balawa, and Rasiah. "Tradisi Khabanti Kantola Sebagai Model Pendidikan Karakter Terintegrasi Kurikulum Lokal Dalam Pendidikan Seni Budaya Di Sekolah Menengah Kabupaten Muna”. Jurnal Mudra, Vol. 31, No. 1, pp. 78-86, 2016. 
[9] I. Fitriani. "Instilling the Local Wisdom in English Language Teaching through Indonesian Traditional Game". National Seminar Proceeding, Pp. 282-289, 2012.

[10] G. Galang. "Internalization of Philosophical Value "Lagu Macapat" In Guidance And Counseling". Prosiding SNBK (Seminar Nasional Bimbingan dan Konseling), Vol. 1, No. 1, pp. 62-73, 2017.

[11] G. T. Purwaning and Kuswarsantyo. "Nilai Pendidikan Karakter Dalam Ragam Gerak Tari Srimpi Pandelori”. Jurnal Mudra, Vol. 33, No. 2, pp. 182 - 190, 2018.

[12] R. Williams. Vocabulary of Culture of Society. London: Croom Helm Ltd., 1976.

[13] M. Q. Patton. Qualitative Evaluation Methods. Beverly Hills, CA: Sage Publications, 1984.

[14] L. J. Moleong. Metodologi Penelitian Kualitatif (Edisi Revisi). Bandung: PT Remaja Rosdakarya, 2014.

[15] M. N. Huda, Sumarlam, and K. Saddhono. "Pembelajaran Menulis Cerita Rakyat Dengan Bahasa Banyumas sebagai Upaya Pelestarian Kearifan Budaya Lokal". Conference On Language And Language Teaching CLLT, 2017.

[16] K. Maile, K. Uibu, and J. Mikk. "Language Teaching Strategies' Impact on Third-Grade Students' Reading Outcomes and Reading Interest". International Electronic Journal of Elementary Education, Vol. 10, No. 5, pp. 601-610, 2018. DOI: 10.26822/iejee.2018541309

[17] Natale. "Use OF Communication and Technology among Educational Professionals and Families". International Journal of Humanities and Social Science, Vol.10, No. 3, pp. 377384, 2017. Doi. 10.26822/iejee. 2018. 336196

[18] UU Sisdiknas No. 20 tahun 2003 dan Permendiknas No. 22 tahun 2006.

[19] Y. Kartini. Lagu Dolanan Anak-anak berbahasa Jawa Sumber Pembentukan Watak dan Budi Pekerti. Sidoarjo: Balai Bahasa Provinsi Jawa Timur. Kemendiknas, 2014.

[20] A. Abdullah. "Kesenian Ojhung Dalam Tradisi Sedekah Bumi Di Desa Bunbarat Kecamatan Rubaru Kabupaten Sumenep Tahun 1960-2005”. Avatara: e-Journal Pendidikan Sejarah. Vol. 5, No. 1, pp. 81-90, 2017.

[21] B. Abdul. "Nilai Pendidikan Islam Dalam Budaya Tenongan Nyadran Suran di Dusun Giyanti Wonosobo". Jurnal Kependidikan Al-Qalam, Vol. IX, 69-78, 2013.

[22] K. Saddhono, "Cultural and social change of foreign students in Indonesia: The influence of Javanese Culture in Teaching Indonesian to Speakers of Other Languages (TISOL)." IOP Conf. Ser.: Ear. and Envi. Sci.. vol. 126 no. 1 IOP Publishing, 2018. 